\title{
Analysis of South Korea's Direct Investment in China
}

\begin{abstract}
Xiaohong Zhan ${ }^{*}$
ABSTRACT

Using a dynamic perspective this article examines, the general situation of the development of South Korean direct investment in China since 1992, when the two countries established diplomatic relations. It probes many characteristics of South Korean direct investment in China: its late start yet rapid rise; the smaller average value of Korean project investments; the accelerated process of localization by large South Korean enterprises in China; the diversified industrial distribution; and the wide-ranging geographical distribution. It analyses the reasons for the rapid increase in South Korean investment in China: the use of China's low-priced production factors, the direct entry of South Korean enterprises into the Chinese market, and the stable investment environment with fewer labor disputes that China provides. Finally, this article also proves that South Korean enterprises have achieved satisfactory results from their direct investment in China.
\end{abstract}

Keywords: Foreign Direct Investment, Investment Environment, Return on Investments.

\section{GENERAL SITUATION OF SOUTH KOREA'S DIRECT INVESTMENT IN CHINA}

South Korea's investment in China has increased dramatically since 1992, when the two countries formally established diplomatic relations. According to China's statistics, in 1992, South Korea's direct investment in China was only US $\$ 119$ million. By 2002 , it reached US $\$ 2.721$ billion - an average 26.8 per cent annual growth. This was much higher than the average annual growth of investment by other countries in China, which stood at 10.9 per cent. In the past two years, in particular, South Korea has become one of the most important investors in China.

Table 1 shows that by the end of 2002 , South Korea was seventh among the top 15 countries and regions with the most direct investment in China. Projects invested in by South Korea accounted for 5.2 per cent of the total number of foreign-invested projects in China; its contractual investments accounted for 3.3 per cent of the overall contractual investments by foreign investment; the actual paid-in investments by South Korea was 3.4 per cent of the overall actual paid-in investments by foreign countries.

\footnotetext{
- Xiaohong Zhan, senior research fellow and executive director of the Economic Research Journal, the Institute of Economics




Table 1. Top 15 Countries and Regions with the Most Investment in China by the End of 2002

(Unit: US\$10,000)

\begin{tabular}{l|r|r|r|r|r|r}
\hline \multicolumn{1}{c|}{ Countries/regions } & $\begin{array}{r}\text { Number } \\
\text { of } \\
\text { Projects }\end{array}$ & $\begin{array}{r}\text { Ratio } \\
\text { to the } \\
\text { total }\end{array}$ & $\begin{array}{r}\text { Contractual } \\
\text { investment }\end{array}$ & $\begin{array}{r}\text { Ratio } \\
\text { to the } \\
\text { total }\end{array}$ & $\begin{array}{r}\text { Actually } \\
\text { utilized } \\
\text { investment }\end{array}$ & $\begin{array}{r}\text { Ratio } \\
\text { to the } \\
\text { total }\end{array}$ \\
\hline \hline Hong Kong & 210,876 & 49.71 & $37,380,600$ & 45.14 & $20,487,523$ & 45.73 \\
\hline United States & 37,280 & 8.79 & $7,628,190$ & 9.21 & $3,988,943$ & 8.9 \\
\hline Japan & 25147 & 5.93 & $4,953,212$ & 5.98 & $3,633,986$ & 8.11 \\
\hline Taiwan & 55,691 & 13.13 & $6,147,086$ & 7.42 & $3,311,028$ & 7.39 \\
\hline Virgin Islands & 6,659 & 1.57 & $4,934,803$ & 5.96 & $2,438,765$ & 5.44 \\
\hline Singapore & 10,727 & 2.53 & $4,014,955$ & 4.85 & $2,147,270$ & 4.79 \\
\hline South Korea & 22,208 & 5.24 & $2,747,593$ & 3.32 & $1,519,896$ & 3.39 \\
\hline United Kingdom & 3,418 & 0.81 & $1,963,261$ & 2.37 & $1,069,550$ & 2.39 \\
\hline Germany & 3,053 & 0.72 & $1,432,209$ & 1.73 & 799,367 & 1.78 \\
\hline France & 2,033 & 0.48 & 719,215 & 0.87 & 554,335 & 1.24 \\
\hline Macao & 7,827 & 1.85 & $1,079,181$ & 1.3 & 477,322 & 1.07 \\
\hline Holland & 1,065 & 0.25 & 897,448 & 1.08 & 433,815 & 0.97 \\
\hline Cayman Islands & 706 & 0.17 & 948,071 & 1.14 & 380,333 & 0.85 \\
\hline Canada & 6,040 & 1.42 & $1,037,740$ & 1.25 & 335,789 & 0.75 \\
\hline Malaysia & 2,538 & 0.60 & 620,053 & 0.75 & 283,544 & 0.63 \\
\hline Others & 28,928 & 6.82 & $6,302,364$ & 7.61 & $2,935,131$ & 6.55 \\
\hline In aggregate & 424,196 & 100 & $82,805,981$ & 100 & $44,796,597$ & 100 \\
\hline
\end{tabular}

Source: Dept. of Foreign Investment Administration of the Ministry of Commerce, People's Republic of China

In 2002, South Korea became China's sixth largest foreign direct investor. Its direct investment in China was US $\$ 2.721$ billion, accounting for 5.2 per cent of China's overall foreign direct investments in that year.

Table 2. Top 15 Countries and Regions with the Most Investment in China in 2002

(Unit: US\$10,000)

\begin{tabular}{l|r|r|r|r|r|r}
\hline \multicolumn{1}{c|}{ Countries/regions } & $\begin{array}{r}\text { Number } \\
\text { of } \\
\text { Projects }\end{array}$ & $\begin{array}{r}\text { Ratio } \\
\text { to the } \\
\text { total }\end{array}$ & $\begin{array}{r}\text { Contractual } \\
\text { investment }\end{array}$ & $\begin{array}{r}\text { Ratio } \\
\text { to the } \\
\text { total }\end{array}$ & $\begin{array}{r}\text { Actually } \\
\text { utilized } \\
\text { investment }\end{array}$ & $\begin{array}{r}\text { Ratio } \\
\text { to the } \\
\text { total }\end{array}$ \\
\hline \hline Hong Kong & 10,845 & 31.74 & $2,520,183$ & 30.45 & $1,786,093$ & 33.96 \\
\hline Virgin Islands & 1,959 & 5.73 & $1,264,980$ & 15.28 & 611,739 & 11.6 \\
\hline United States & 3,363 & 9.84 & 815,647 & 9.85 & 542,392 & 10.28 \\
\hline Japan & 2,745 & 8.03 & 529,804 & 6.4 & 419,009 & 7.94 \\
\hline Taiwan & 4,853 & 14.2 & 674,084 & 8.14 & 397,064 & 7.53 \\
\hline South Korea & 4,008 & 11.73 & 528,222 & 6.38 & 272,073 & 5.16 \\
\hline Singapore & 930 & 2.72 & 278,548 & 3.37 & 233,720 & 4.43 \\
\hline Cayman Islands & 199 & 0.58 & 225,773 & 2.73 & 117,954 & 2.24 \\
\hline Germany & 352 & 1.03 & 91,532 & 1.11 & 92,796 & 1.76 \\
\hline United Kingdom & 334 & 0.98 & 114,199 & 1.38 & 89,576 & 1.7 \\
\hline West Samoa & 533 & 1.56 & 187,782 & 2.27 & 87,947 & 1.67 \\
\hline Canada & 708 & 2.07 & 114,843 & 1.39 & 58,798 & 1.11 \\
\hline France & 162 & 0.47 & 87,886 & 1.06 & 57,560 & 1.09 \\
\hline Holland & 127 & 0.37 & 51,629 & 0.62 & 57,175 & 1.08 \\
\hline Mauritius & 245 & 0.72 & 70,477 & 0.85 & 48,369 & 0.92 \\
\hline In aggregate & 34,171 & 100 & $8,276,833$ & 100 & $5,274,286$ & 100 \\
\hline
\end{tabular}

Source: Dept. of Foreign Investment Administration of the Ministry of Commerce, People's Republic of China 
It is important to highlight that statistics released by the two countries on South Korea's Chinabound direct investment are different. For example, the Chinese side estimated the figure in 2002 to be US $\$ 2.721$ billion, while the Korea National Statistical Office's figure stood at US\$1.72 billion. Obviously, the Korean side did not take some part of the investments into account.

In the past two years, the ratio of South Korea's investment in China to China's overall foreign direct investment has been rising rapidly. According to the Department of Foreign Investment Administration in China's Ministry of Commerce, in 2003 China ushered in US\$53.5 billion worth of foreign direct investment, an increase of 1.4 per cent year to year. Direct investment from South Korea was US $\$ 4.49$ billion that year, up 65 per cent over the previous year. It accounted for 8.4 per cent of China's overall foreign direct investment in 2003, making the country China's fourth largest foreign direct investor. The gap between South Korean and Japan, China's third largest foreign direct investor, whose direct investment in China was US\$5.05 billion in 2003, was not significantly large. In the first half of 2004, China attracted US\$32.9 billion worth of foreign direct investment, an increase of 12 per cent year to year. South Korea's direct investment in China during that period was US\$3.52 billion, an increase of 54 per cent year to year. It accounted for 10.7 per cent of China's overall foreign direct investment during the same period, enabling the country to replace Japan (with a foreign direct investment of US\$2.947 billion in China) as China's third largest foreign direct investor. By the end of 2003, South Korea's aggregate investment in China was US\$19.688 billion. According to an economic councillor from the South Korea Embassy in China, in 2003, on average, there were 12 enterprises investing in China every day, with a total investment of US\$13 million.

Table 3. Growth of South Korea's Investment in China in Recent Years

\begin{tabular}{|c|c|c|c|c|c|c|}
\hline Year & $\begin{array}{r}\text { China's } \\
\text { aggregate } \\
\text { foreign } \\
\text { investment }\end{array}$ & Growth & $\begin{array}{r}\text { South } \\
\text { Korea's } \\
\text { China-bound } \\
\text { investment }\end{array}$ & Growth & $\begin{array}{r}\text { Ratio to } \\
\text { China's } \\
\text { foreign } \\
\text { investment }\end{array}$ & Rank \\
\hline & $\begin{array}{r}\text { US\$100 } \\
\text { million }\end{array}$ & $\%$ & $\begin{array}{r}\text { US\$100 } \\
\text { million } \\
\end{array}$ & $\%$ & $\%$ & \\
\hline 2000 & 407.1 & & 14.89 & $z$ & 3.6 & \\
\hline 2001 & 468.7 & 19.6 & 21.51 & 44.45 & 4.6 & \\
\hline 2002 & 427.4 & 12.5 & 27.21 & 26.44 & 2.2 & 5 \\
\hline 2003 & 535 & 1.4 & 44.9 & 6.5 & 8.4 & 4 \\
\hline $2004^{*}$ & 329 & 12.0 & 35.2 & 54.4 & 10.7 & 3 \\
\hline
\end{tabular}

Note: First six months only.

Source: The author compiled the statistics from Chinese newspapers, magazines and relevant websites.

South Korea's China-bound investment also carries a big weight in its overseas investment. According to a Yonhap News Agency report from Seoul on 11 August 2004, the ratio of the country's China-bound direct investment to its overseas investment was 11.4, 29.2 and 37 per cent in 2001, 2002, and 2003 , respectively. In the first half of 2004 , the ratio further rose to 43.5 per cent. According to a 24 August 2004, report released by the Korea International Trade Associations, by the end of last June, there were 6,620 South Korean enterprises investing overseas. More than 40 per cent, or 2,888, of those enterprises are in China. 


\section{CHARACTERISTICS OF SOUTH KOREA'S INVESTMENT IN CHINA}

\section{Late Start but Rapid Rise}

In 1992, when the two countries established diplomatic relations, South Korea invested a negligible US\$119 million in China, which accounted for only a meagre proportion of China's foreign investment. In the following decade, investment from South Korea became the most important source of China's foreign investment. Between January and August 2004, investment by South Korean enterprises in China accounted for nearly 11 per cent of China's incoming foreign investment. Excepting free ports such as Hong Kong and the Virgin Islands, South Korea has taken the place of the United States and Japan to become China's largest foreign investment source. In recent years, the position of South Korean investment in China's foreign investment has risen ever year.

The investing momentum of South Korean enterprises in China is also strengthening. According to a 13 July 2004, report by the Yonhap News Agency from Seoul, The Federation of Korean Industries (FKI) released a report entitled the Study on the Current Situation and Further Improvement of Investment by South Korean Enterprises in China on that same day based on survey results from 254 out of the top 700 South Korean enterprises in China (in terms of value of investment). Concerning investment plans in the following five years, 43.7 per cent of the surveyed enterprises answered that they would "reduce domestic investment and expand investment in China." On the contrary, only 6.1 per cent of the surveyed enterprises said they would "reduce the proportion of their investment in China and increase domestic investment." In addition, many South Korean enterprises investing in the United States and Europe have moved their firms to China in the past few years.

\section{Smaller Average Value of Project Investments}

Analysing the statistics in Table 1 and Table 2 draws the following conclusion. By the end of 2002, the average value of each project invested in by the top 15 countries and regions in China was US\$1.05 million while those of South Korean enterprises was only US\$684,000. In 2002, the average value of each project invested in by the top 15 countries and regions in China rose to US\$1.54 million while those of South Korea remained at US\$680,000. According to statistics released by relevant South Korean departments, the average value of each project invested in by South Korean enterprises in China was also around US\$1 million, much less than that in other countries.

Obviously, the small volume of project investments by South Korean enterprises in China is due to the fact that most of the South Korean enterprises in China are small to medium-sized enterprises.

\section{Acceleration of the Pace of Localization by Large South Korean Enterprises in China}

It is worth elaborating on the investments by big South Korean enterprises, such as the Samsung Electronics Co., Ltd, Hyundai Motor Company and the LG Group. In April 1992, Samsung established its first joint-venture subsidiary in China in Tianjin. By August 2002, Samsung had established one investment company, 24 production plants, four marketing enterprises, one R\&D center and one sales service company. Samsung's aggregate investment value is US $\$ 2.3$ billion and its employment in China is numbered at 38,000 . In 2003, in particular, Samsung recruited only 6,700 employees from South Korea while in China it employed 9,000 workers and managers. Its sales volume in China has increased dramatically: in 2002 , it was US\$6 billion, in 2003, it rose to US\$8 billion and it is expected to reach US $\$ 10$ billion in 2004. Sixty per cent of its products have been sold on international markets.

The Hyundai Motor Company entered the Beijing market only two years ago. With its Chinese partner, the company has developed at a rapid pace. On 13 December 2002 the joint venture's first car rolled off the production line. On 14 June 2003 the company had produced and sold 20,000 cars. By 14 
April 2004 the company had produced and sold 50,000 cars and the aggregate volume is expected to reach between 100,000 and 150,000 by the end of 2004. In 2005 it is expected to reach 300,000 . The success of the initial investment marked by the rapidly increased production and sales has greatly buoyed the spirit of both sides. By 2007 both joint venturers are planning an increase of US\$740 million worth in investments, respectively to establish the second Hyundai joint-venture subsidiary in Beijing. By 2008 he company hopes to reach a production and sales volume of 600,000 . Hyundai's investment in Beijing has invigorated local economic development. The Beijing Daily News reported that in 2003, the output value of the Beijing Hyundai Motor Company accounted for 12 per cent of the value of Beijing's overall industrial output.

In Beijing's Central Business District, there is a 40 storey "Beijing Tower," which resembles the LG headquarters in Seoul. This tower is the site of LG's headquarters in China. LG subsidiaries in China now have 11,000 employees, 98 per cent of whom are Chinese. In 2002, the sales volume of the company was US\$4 billion and in 2003 it rose to US\$7 billion.

South Korean enterprises have higher ambitions than just turning China into its largest manufacturing center. They have also coordinated their production, sales, and R\&D capacities. As the volume of investment by South Korean enterprises in China grows, South Korean enterprises have all established their "China headquarters", or "second headquarters", in China in recent years. The presidents of Samsung, LG, and Hyundai have all expressed their hope that the "second Samsung", the "second LG", or the "second Hyundai" can be established in China. They have paid attention to "localizing" their subsidiaries; along with the labor force, some senior managers in Korean enterprises are Chinese.

\section{Industrial Distribution of South Korean Enterprises}

According to statistics from the Export-Import Bank of Korea manufacturing projects between 1993 and 2000 accounted for 87.2 per cent of the direct investment projects by South Korean enterprises in China. The investment volume of these manufacturing projects accounted for 85.6 per cent of South Korean enterprises in China. There are among the South Korean manufacturing industries in China both labor-intensive manufacturing sectors, such as garment, textile, shoes, and furniture, and capital-intensive manufacturing sectors, such as metal components and petrochemical industries. Among these, garment and textile industries comprise the largest proportion, accounting for 20.8 per cent, in terms of number of projects. In terms of investment volume, the metal component sector at 31.3 per cent represents the largest part. According to an analysis by an economic councillor of the South Korea Embassy in China the main fields of investment by South Korean firms in China in recent years are mainly the information technology (IT), petroleum, chemical, steel, and auto industries. It is predicted that the focus of investment by South Korean firms may shift from the manufacturing industries to the service sectors and from the coastal areas to the inland.

A South Korean economist predicted "after five years, China will become South Korea's most important cooperative partner in terms of comprehensive dependency in multiple fields, including financial and technological services."

\section{Geographical distribution of South Korean enterprises in China}

Out of geographical and linguistic considerations, at the initial stage of entering China, South Korean investors mainly concentrated their investment on Heilongjiang, Jilin, and Liaoning in Northeast China, as well as Beijing, Hebei, and Shandong. Those regions accounted for more than 85 per cent of South Korea/s investment in China during the period from 1993-2000. In recent years, however, there has appeared a trend of South Korean investment moving southward. In both 2002 and 2003, South Korea had become a source of foreign investment in Shandong. The proportions of South Korean 
investments to the total of foreign investments in Shandong were 23 and 27 per cent, respectively. A recent article carried by the JoongAng Ilbo said that last year Jiangsu Province became the No.1 recipient of South Korea's foreign investment in China. Foremost among all the provinces receiving South Korean investment, Jiangsu's proportion rose from 15.4 per cent in 2003 to last year's 22.8 per cent. An increasing proportion of South Korean investment has also affected cities in the Pearl River Delta region, where preferential policies have been implemented to attract South Korean investors.

\section{REASONS FOR THE DRAMATIC GROWTH IN SOUTH KOREA'S INVESTMENT IN CHINA}

China and South Korea are highly complementary in many aspects, such as natural resources, labor, industrial structure, commodity market, capital, technology, and corporate management. Scarce land resources and an inadequate and costly labor force limit South Korea. Also, its domestic market is constrained. On the other hand, it has some advantages in capital, technology, and management. Those factors have pushed the country's enterprises to invest in China on a large scale. In the following paragraph, this argument will be justified by citing research reports by the country's relevant government departments and opinion polls published by local media.

\section{Making Use of China's Relatively Low-priced Production Factors}

China boasts low-priced land and labor prices. According to a 26 August 2003, article published in Chosun Ilbo, the average monthly pay of South Korean workers in the manufacturing industries was US $\$ 1,524$ in 2002, the second highest in Asia after Japan. Chinese workers in the manufacturing industries earned US\$111 a month on average, only one fourteenth of what is made in South Korea. The Chosun Ilbo published a Federation of Korean Industry (FKI) research report on 25 August 2004, analysing reasons for South Korean enterprises shifting their investments to China. The report compared the Qingdao Industrial Park in China's Shandong Province and the Banwol-Sihwa Industrial Park. The labour costs of industrial parks in South Korea are ten times more costly than those in Chinese industrial parks, and land prices of South Korean parks are nearly forty times more expensive than those in Chinese parks. In the Qingdao Industrial Park, the production workers' average monthly salaries ranges from 70,000 to 112,000 won. In contrast, the average monthly pay for production workers in the BanwolSihwa Industrial Park exceeds one million won. Regarding prices of land for factory construction, in Qingdao it is 14,700 won per square metre while it is about 606,000 won per square metre in the Banwol-Sihwa Industrial Park. The tax level in South Korea is also about twice as high as that in China. When considering government support such as tax preferential policies, the gap between the two countries is even wider. The corporation tax in the Banwol-Sihwa Industrial Park is 27 per cent, which is much higher than that of Qingdao Industrial Park, which stands at 15 per cent. Prices of water and electricity for industrial use, which are both indispensable for industrial operation, are also 1.5 and 1.9 times higher respectively in the Banwol-Sihwa Industrial Park than in the Qingdao Industrial Park.

\section{Entering the Chinese Market}

China's high-rate of economic growth and huge market potentials have made South Korean investors confident in investing in the country. Inevitably, China's high-rate economic growth will definitely lead to stronger consumer demand. Moreover, as China has joined the World Trade Organization (WTO), the domestic market will be further opened up. This is undoubtedly a great incentive for South Korean enterprises.

The Korea Chamber of Commerce and Industry and the Korea Chamber of Commerce and Industry in China recently surveyed 256 South Korean enterprises investing in China on their motives for China-bound investment. The results show that making use of China's low-priced labor is the No. 1 
factor (51.4 per cent) considered among all the factors pushing South Korean enterprises to invest in China. The second most vital factor is entering the Chinese market ( 30.5 per cent). The FKI holds that most South Korean investors in China emphasized the expanded supply of production equipment aimed to satisfy the domestic demand in the Chinese market. Among the South Korean products manufactured in the Chinese factories, 45.3 per cent are sold on the Chinese market and 54.7 per cent are sold on overseas markets.

\section{China Relatively Stable Investment Environment with Fewer Labor Disputes}

According to the World Competitiveness Yearbook 2003 released by the Switzerland-based Institute for Management Development, South Korea's labor disputes and environment for foreign investment have the worst adverse impact on the country's competitiveness among all OECD members. The number of mass strikes in South Korea has increased steadily in recent years. On average, there were 84 mass strikes between 1995 and 1997. In 2000, there were 250 such incidents. In 2001, there were 321 mass strikes. Between 1998 and 2002, on average the direct economic losses incurred by mass strikes were 1.6 trillion won (about US\$1.34 billion) every year. Another internationally accepted standard for calculating the losses incurred by strikes is the number of non-production days as a result of strikes, or to be more exact, the number of the total non-production days of every 1,000 employees in a year. According to a June 23, 2003, report in the Chosun Ilbo, in 2002, the number was 109 for every 1,000 employees in South Korea; in its rival Japan, the number was 1.9 and in Taiwan it was 0.4. The figure in South Korea was 57 and 272 times greater than those of Japan and Taiwan, respectively.

Faced with an increasing number of labor disputes and frequent strikes, the South Korean enterprises have adopted a "moving away" strategy to circumvent those troubles. Their primary choice is China's mainland.

\section{BENEFIT ANALYSIS OF INVESTMENT IN CHINA BY SOUTH KOREAN ENTERPRISES}

Clearly, the large-scale entry of South Korean investors into China has injected fresh blood into China's economic development. At the same time, the South Korean enterprises are generally satisfied with the returns of their investment in China.

The Export-Import Bank of Korea released a report on the operational situation of investments by South Korean corporations in China on 16 February 2004. According to the report, by the end of 2002, performance comparisons between investments by 66 South Korean corporations in China and 318 South Korea corporations in other parts of the world - both with an investment of more than US\$10 million? show that those in China had better operational records than those in other regions. The report stated that the average current net revenues of investments by South Korean corporations in China were US $\$ 280$ million, much higher than the average level of US $\$ 70$ million achieved by South Korean corporations in other countries. Over three-quarters of investments ( 77.3 per cent) made by South Korean corporations in China were profitable. The proportion was much higher than that in other countries (61.9 per cent). The sales volume China-based South Korean corporations had grown by 33.7 per cent year a year on average, 23.2 percentage points higher than South Korea corporations in other countries. This also served as proof of China's vigorous economic growth. The asset-liability ratio of those South Korean corporations in China was 143.6 per cent, much lower than that of South Korean corporations in other countries, which stood at 358.7 per cent. This fully testified to the sound and stable financial structure and condition of those the investments by South Korean corporations in China. The rate of return on investments in the South Korean corporations in China was 10.8 per cent, which is also higher than the rate of 7.6 per cent by South Korean corporations in other countries. 
In addition, according to the results of a 5 September survey conducted by the Korea Federation of Small and Medium Business, of 102 Korean enterprises entering China, 57.4 per cent of those surveyed said they are satisfied with the results of their investment in China while only 13.8 per cent of those firms said they feel dissatisfied. 38 per cent of those surveyed said they are making profits. 31 per cent said they maintain a balance between revenue and expenditure. Another 31 per cent said they are running at a loss.

A Federation of Korean Industries (FKI) report released in July 2004, held that among South Korean enterprises operating in China, nearly half of them operate soundly and 66.4 per cent of those firms are very or basically satisfied with the results of their investment in China. If a comprehensive appraisal is made by taking into consideration such factors as the soundness of the operation of South Korean enterprises in China, results of their investment and level of localization, it can be concluded that those enterprises have been fairly successful operating in the Chinese market.

\section{CONCLUSION}

This article uses a large quantity of first-hand materials to prove that, since the two countries established diplomatic relations, South Korean direct investment in China has increased rapidly. It has grown at a pace much faster than that of investments in China by other countries. In 2004, South Korea became the most important foreign investor in China. Characteristics of South Korean direct investments in China are as follows. Firstly, it started late but has grown rapidly. Second, the values of the project investments are small - they are only US $\$ 600,000$ to US $\$ 700,000$ on average, while values of projects directly invested in by other countries in China are more than US $\$ 1$ million on average. This is related to the fact that South Korean enterprises investing in China are mostly small to medium-sized ones. While continually increasing investment in China, big South Korean conglomerates, such as Samsung Electronic Electronics Co., Ltd, Hyundai Motor Company, and the LG Group have accelerated their localization processes in China. The industrial distribution of South Korean direct investment in China has shifted from labor-intensive industries to capital and knowledge-intensive ones. Regions of investment have spread from the Northeast and North provinces at the initial stage to East China, the Yangtze River Delta region, and South China's Pearl River Delta. The key to South Korean enterprises in China is China's relatively low-priced labor and land, as well as the stable social investment environment. They hope to make use of their direct investment to enter the central region of China's vast market. The reality has proved that most South Korean enterprises have achieved satisfactory results from their direct investments in China.

\section{REFERENCES}

The Chosun Ilbo, Dong-A Ilbo, Yonhap News Agency website (in Chinese), from July 2003 to October 2004.

Department of Foreign Investment Administration of the Ministry of Commerce, China. http://www.fdi.gov.cn

Wang Xindong, 2003, Analysis of South Korean Investment in Shandong, China, published in Forecast magazine (sponsored by the Korea Chonnam Institute of Development) 7, 45-60.

Huang Fanhua, 2002, Analysis of Structure of South Korea's Direct Investment in China, published in Foreign Economy and Management 9, 33-42. 